\title{
The behaviour of licking the everted rectum in shrews (Soricidae, Insectivora)
}

\author{
Hirofumi HIRAKAWA and Werner HABERL
}

\begin{abstract}
Hirakawa H. and Haberl W. 1998. The behaviour of licking the everted rectum in shrews (Soricidae, Insectivora). Acta Theriologica: 43: 113-120.

The behaviour of licking the everted rectum in shrews, hitherto referred to as "coprophagy" or "refection" is reviewed. To avoid confusion with "true" faeces-eating, it is proposed to persistently use the descriptive term "rectum-licking" when referring to this phenomenon. The behaviour is characterized by the animal everting the rectum by a series of abdominal contractions and licking it in a curled-up posture, apparently ingesting a yet undetermined substance often described as a "milky white fluid". This behaviour has been reported repeatedly, but most previous observations are only fragmentary and the accounts on the generality, frequency, rhythm, timing, mechanism, and functions of the behaviour are not all consistent. Rectum-licking is certainly an infrequent and elusive behaviour, which can be mistaken for other behaviours that share the same curled-up posture. Further studies are required to elucidate this behaviour.

Forestry and Forest Products Research Institute, Hitsujigaoka 7, Toyohira, Sapporo 062-8516, Japan, e-mail: hiroh@ffpri-hkd.affrc.go.jp (HH); Hamburgerstrasse 11/17, A-1050 Vienna, Austria, e-mail: shrewbib@sorex.vienna.at (WH)

Key words: Soricidae, shrews, rectum-licking, coprophagy, refection, behaviour
\end{abstract}

\section{Introduction}

The behaviour of licking the everted rectum has been reported repeatedly in many shrew species since first described by Crowcroft (1952). However, because it has been observed infrequently and often casually our understanding of this phenomenon is poor. In this review, we examine descriptions from published accounts and undocumented observations acquired through extensive inquiries, summarize our present knowledge of this phenomenon, and make suggestions for further studies.

\section{Terminology}

Two terms have been used to refer to rectum-licking behaviour: "coprophagy" (Sharma 1962, Imaizumi 1964, Loxton et al. 1975, Hutterer 1976) and "refection" (Crowcroft 1952, 1957, Spencer-Booth 1956, Imaizumi 1964, Baxter and Meester 
1980, 1982, Churchfield 1990). However, since the origin and the composition of the substance licked from the everted rectum are yet unknown, the term "coprophagy", etymologically meaning faeces-eating, apparently is not appropriate. Nor is the term "refection" appropriate because it means "the habit of an animal eating its own faeces" (Gove 1976, Lincoln et al. 1982) and has been used to describe coprophagy in rodents and lagomorphs where faeces are taken directly from the anus to the mouth (eg Southern 1942 ), although since Watson (1954) "reingestion" is more commonly used for this behaviour (eg Hirakawa 1994).

The use of "coprophagy" and "refection" is not only inappropriate but also confusing because shrews actually eat faeces (coprophagy in its true sense), either directly from their anus (refection) (Luk'yanova 1974, Loxton et al. 1975, Geraets 1978, Baxter and Meester 1982, G. L. Dryden, S. Oda, N. A. Shchipanov, pers. comm.), or from a deposited faecal pile (Hutterer 1976, Skarén 1978, Baxter and Meester 1982, O. B. Mock, pers. comm.). Consequently, we propose to simply describe it as "the behaviour of licking the everted rectum", or in short "rectum-licking" as Geraets (1978) suggested.

\section{General description of the behaviour}

There is a detailed description of the rectum-licking behaviour in Sorex araneus by Crowcroft (1952): the animal adopts a curled-up position upon its side or back, parts the hind-limbs and begins to lick the anus; a few seconds later, a rapid series of abdominal contractions brings about the gradual eversion of the rectum, which emerges as a stout firm tube, $5-10 \mathrm{~mm}$ long; the open end of the everted rectum is nibbled and licked for a period less than ten minutes; inversion into the body is again effected by abdominal movements. The rectum is "erected" but can become flaccid when shrews are handled.

There are similar descriptions of Sorex shinto by Imaizumi (1964), Suncus etruscus by Fons (1974), and Crocidura hirta, C. flavescens, and Myosorex varius by Baxter and Meester $(1980,1982)$. Imaizumi (1964) further stated that the shrew gripped the everted rectum with the forefeet while licking and that the rectum was taken in and out several times for 10-15 minutes. Baxter and Meester (1980, 1982) and Fons (1974) observed shrews alternating the side on which they were lying. Geraets (1978) noted that not only the opening of the everted rectum, but also its lateral side were nibbled.

Rectum-licking is reported from both sexes and from both young and adult shrews (Crowcroft 1952, Hutterer 1976, Fons 1974, Geraets 1978, Haberl 1993). It is practiced predominantly in nests (Crowcroft 1952, Spencer-Booth 1956, Imaizumi 1964, Geraets 1978, Churchfield 1990), although Imaizumi (1964) stated that "during the steaming hot season" it was often performed outside of the nest. Baxter and Meester $(1980,1982)$ observed that a corner of the cage or some object was often used to provide support for the awkward posture. 
The rectum is often observed being everted in shrews although the context regarding rectum-licking is not necessarily clear (K. Koyasu, P. Vogel, pers. comm.). S. Oda (pers. comm.) observed Suncus murinus keeping the rectum everted for more than one hour, sometimes even for almost a whole day. The everted rectum is also often observed in seemingly starved or starved-to-death shrews in traps or in captivity (Sharma 1962, Fons 1974, P. Vogel, pers. comm.).

For photos of the everted rectum and rectum-licking behaviour, refer to Imaizumi (1964) and Haberl et al. (1997). Barnard (1984) has a photo of a curled-up posture of Sorex minutus, where however the eversion of the rectum is not visible. A slide preparation of the everted rectum is illustrated in Geraets (1978).

\section{Species in which rectum-licking has been observed}

It seems that this behaviour is widely practiced among Soricidae. Hitherto, it has been reported in seven genera of Soricidae: Blarina, Crocidura, Myosorex, Neomys, Notiosorex, Sorex, and Suncus. The following list excludes accounts that appeared to refer to faeces-eating or genital-licking (see below "Similar behaviours"):

\begin{tabular}{|c|c|}
\hline Species & References \\
\hline Blarina brevicauda (Say, 1823) & E. D. Brodie Jr, pers. comm. \\
\hline Crocidura dsinezumi (Temminck, 1844) & K. Ohno, pers. comm. by K. Koyasu \\
\hline Crocidura flavescens (I. Geoffroy, 1827) & Baxter and Meester 1982 and pers. comm. \\
\hline Crocidura hirta Peters, 1852 & Baxter and Meester 1980 \\
\hline Crocidura olivieri (Lesson, 1827) & P. Vogel, pers. comm. \\
\hline Crocidura russula (Hermann, 1780) & Geraets 1978, P. Vogel, pers. comm. \\
\hline Crocidura suaveolens (Pallas, 1811) & $\begin{array}{l}\text { Spencer-Booth } 1956 \text {, Geraets } 1978, \text { N. Roteri, pers. } \\
\text { comm., and S. Hellwing, pers. comm. by N. Roteri }\end{array}$ \\
\hline Myosorex varius (Smuts, 1832) & Baxter and Meester 1980 \\
\hline Neomys anomalus Cabrera, 1907 & Geraets 1978 \\
\hline Neomys fodiens (Pennant, 1771) & Geraets 1978, D. Köhler, pers. comm. \\
\hline Notiosorex crawfordi (Coues, 1877) & J. E. Maldonado, pers. comm. \\
\hline Sorex araneus Linnaeus, 1758 & $\begin{array}{l}\text { Crowcroft 1952, Loxton et al. 1975, Hutterer 1976, } \\
\text { Haberl 1993, D. Köhler, P. Vogel, S. Churchfield, } \\
\text { pers. comm. }\end{array}$ \\
\hline Sorex cinereus Kerr, 1792 & E. Gould, pers. comm. \\
\hline Sorex minutus Linnaeus, 1766 & $\begin{array}{l}\text { Crowcroft 1957, Hutterer 1976, S. Churchfield, } \\
\text { pers. comm. }\end{array}$ \\
\hline Sorex ornatus Merriam, 1895 & J. E. Maldonado, pers. comm. \\
\hline Sorex palustris Richardson, 1828 & E. Gould, pers. comm. \\
\hline Sorex shinto Thomas, 1905 & Imaizumi 1964 \\
\hline Suncus murinus (Linnaeus, 1766) & $\begin{array}{l}\text { Sharma 1962, Geraets } 1978, \text { J. M. Bedford, } \\
\text { G. L. Dryden, S. Oda, pers. comm. }\end{array}$ \\
\hline Suncus etruscus (Savi, 1822) & Geraets 1978, Fons 1974 \\
\hline
\end{tabular}


There are no accounts of rectum-licking from insectivores other than Soricidae. Imaizumi (1964) reported that he did not observe rectum-licking in Urotrichus talpoides and Mogera wogura (= M. imaizumii according to Abe 1996, Motokawa and Abe 1996) (Talpinae) kept in captivity for two years. E. Gould (pers. comm.), having worked with Tenrecidae and Hylomyinae for a long time, states that he has no record of this behaviour in these insectivores.

\section{The licked substance}

When dissecting Sorex araneus immediately after rectum-licking, Crowcroft (1952) found a "milky white fluid" in the stomach and the proximal part of the small intestine, the remainder of the intestine and the rectum being completely empty. Crowcroft's findings are concordant with the observations by Fons (1974) in Suncus etruscus (killed and dissected when found in traps with the rectum being everted) and Geraets (1978) (describing a white liquid in all parts of the digestive tract in dissected animals).

Accounts of this "milky fluid" actually being licked from the everted rectum are by Loxton et al. (1975), Geraets (1978), Churchfield (1990), and G. L. Dryden (pers. comm.). Geraets (1978) noticed twice that Suncus murinus licked a whitish liquid from the fold between the anal edge and the everted rectum. Contrary to Crowcroft's (1957) statement, that the fluid 'appeared' to contain numerous fat globules and small fragments of undigested food, Geraets implicitly suggested that the substance could be a secretion from the proctodaeal gland. G. L. Dryden (pers. comm.) states that $S$. murinus lick "strings of white mucoid material" from the everted rectum, which possibly derives at least in part from the "anal tonsils" described by Dryden and Conaway (1970). However, not all shrew species have this tissue (Ortmann 1960). For a detailed description of the glands present in the ano-genital region, refer to Ortmann (1960), Bee et al. (1980) and Kubo and Isomura (1996).

\section{Frequency and rhythm}

The frequency and the rhythm of rectum-licking were systematically studied in $S$. araneus (Loxton et al. 1975): in 19 observational periods, each of 24 hours, it occurred 26 times, predominantly during the daytime, when activity and food intake were low. Geraets (1978) observed it during day- and night-time but seldom more than once during 8-12 hours. Baxter and Meester (1982) noticed it in Crocidura flavescens only during daylight hours.

However, there seems to be a great variation among individuals, some not performing the behaviour at all within 24 hours (Loxton et al. 1975). Sharma (1962) noticed rectum-licking in Suncus murinus several times during the 12-year study, but none of the three animals observed for over 36 hours practiced the 
behaviour. Imaizumi (1964) repeatedly observed it in Sorex shinto, kept in captivity for four months, but stated that it was difficult to ascertain its frequency.

\section{Timing, mechanism and functions}

Crowcroft (1952) noted that while rectum-licking in shrews may imply analogous nutritional consequences with the refection in rodents, the mechanism involved must be quite different as shrews have no caecum; it is a normal physiological process rather than one occasioned by diet deficiency in captivity, although he stated that "it does not commence until the gut is entirely free of faecal matter". He also suggested that the process may be brought about by a periodic cessation in the flow of digestive fluids, based on the observation that the faeces became progressively lighter in colour prior to rectum-licking and that the intestine was completely free of the green bile when the behaviour occurred (Crowcroft 1952, 1957).

Sharma's (1962) proposal that Suncus murinus may resort to the behaviour only when faced with starvation finds support by the observations of either the behaviour itself or the finding of the still everted rectum in seemingly starving or starved-to-death shrews in traps (Fons 1974, P. Vogel, pers. comm.). However, the behaviour is also described in apparently healthy animals (Baxter and Meester 1980, Haberl 1993, P. Vogel, pers. comm.) or to occur shortly after feeding (Loxton et al. 1975, J. E. Maldonado, pers. comm.). The latter is contradictory to Crowcroft's (1952) observation that the digestive tract was almost empty (except for a white milky fluid) when shrews were dissected immediately after practicing rectum-licking. Fons (1974) could not experimentally induce rectum-licking by starvation and stated that it could function as cleaning the interior part of the rectum (to remove endoparasites or regain symbiotic bacteria or substances required for digestion).

Loxton et al. (1975) noted that this behaviour might be a means towards "laying up" during the day to compensate for the reduction in food intake or to extract more nutrients from the available food. The function of regaining vitamins (Crowcroft 1957, Walker 1964) still lacks scientific support and is likely to be only a conjecture from refection in rodents and lagomorphs.

Geraets (1978) implicitly suggested that rectum-licking might have a digestive function by citing Schaffer (1940) that the proctodaeal glands of Soricinae are histologically similar to the submaxillary salivary glands; everting the rectum possibly helps to put pressure on these glands.

Although the context is not clear, G. L. Dryden (pers. comm.) observed Suncus murinus eating an unusual "green faecal mass" prior to licking the rectum. Green mucuos-coated faeces are also reported in S. murinus by Geraets (1980) and S. Oda (pers. comm.) and Crocidura dsinezumi by K. Ohno (pers. comm. by K. Koyasu). Geraets (1980) and W. Haberl (unpubl.) observed starved animals producing such faeces (Neomys, Sorex, and Suncus). 


\section{Similar behaviours}

There are four kinds of behaviour similar to rectum-licking, which could confuse the observer, as they require the same curled up posture to reach the ano-genital region with the snout.

Faeces-eating: several authors observed shrews eat faeces directly from the anus (Loxton et al. 1975, Geraets 1978, Baxter and Meester 1982, G. L. Dryden, S. Oda, pers. comm.). However, in this case, the rectum is neither seen (R. M. Baxter, pers. comm.) nor described as being everted. On some occasions shrews have been observed to eat a green mucous faecal mass (see above "Timing, mechanism and functions").

Anus-licking: this behaviour sometimes precedes rectum-licking, possibly to sample the rectal contents (Crowcroft 1952), but it also occurs independently. It is described by Skarén (1978) in Sorex minutissimus after defaecating and by D. Köhler (pers. comm.) in Neomys fodiens after diving or defaecating. Both authors regarded this as a cleaning behaviour.

Genital-licking: this behaviour always occurs in both sexes after mating in Suncus etruscus, but it can also be observed at any other time independent of age (Fons 1974). Female Sorex minutus lick the genital area before parturition (Hutterer 1976).

Erect penis-licking: male shrews lick the erect penis (Hutterer 1976, Geraets 1978, R. M. Baxter, G. L. Dryden, P. Vogel, S. Oda, pers. comm.). According to Geraets (1978), this occurs mostly after waking up, often before or after yawning or stretching. Hutterer (1976) observed a male Sorex minutus contracting the lumbar region, erecting the penis, running dragging the penis behind, then turning on its back and licking the penis, which retracted after a few seconds. G. L. Dryden (pers. comm.) notes that in Suncus, this is usually a post-copulatory behaviour.

\section{Conclusions and suggestions for future studies}

The behaviour of licking the everted rectum is an infrequent and possibly irregular behaviour, which easily escapes observation or can be mistaken for other similar behaviours. The apparent variation among scientists' reports on the frequency indicates that the behaviour may be related to the animals' conditions in captivity or that it may simply be due to the difficulty of observing it when performed inside the nest (note that all the hitherto observations were made in captive animals). The often observed eversion of the rectum may not necessarily be connected with the licking behaviour and could have a completely different or additional significance.

Because the behaviour is widely observed in Soricidae, it is likely to have some adaptive physiological functions. However, this review has revealed a number of contradictory accounts and we are still far from understanding the behaviour. 
Further intensive and deliberate studies, rather than occasional observations, are required to produce the correct picture of the behaviour and clarify its functions.

One of the key issues is to clarify the origin and the components of the licked substance. Besides behavioural observation, anatomical, histological and biochemical analyses will be required. Other important issues are how often and during what timing the behaviour is conducted and how this varies among species. To avoid confusion with other behaviours involving a curled-up posture, it needs to be ascertained in all future studies, that the described behaviour includes the eversion of the rectum. To discuss the evolutionary significance of this phenomenon, it will also be necessary to confirm either the presence or absence of the behaviour in free-ranging shrews and in other insectivores.

We hope this review will encourage further studies and help solve the enigma of rectum-licking behaviour in shrews.

Acknowledgments: We would like to thank the following persons for providing their own accounts and observations: R. M. Baxter, E. D. Brodie Jr, J. M. Bedford, S. Churchfield, T. Curtis, W. Van Devender, G. L. Dryden, E. Gould, J. B. French Jr, R. Hutterer, D. Köhler, J. E. Maldonado, O. B. Mock, D. E. Moore, T. Mori, H. Mover-Lev, S. Oda, S. Ohdachi, Z. Pucek, N. Roteri, N. A. Shchipanov, K. Tsuji, and P. Vogel. Special thanks to K. Koyasu for his help throughout the process of this review. We are indebted to $H$. Abe who focussed our interest on this behaviour. S. Matsuoka and T. Shimada provided important sources of information.

\section{References}

Abe H. 1996. [A review of specific names of Japanese insectivores]. Honyurui Kagaku (Mammalian Science) 36: 96-108. [In Japanese]

Baxter R. M. and Meester J. 1980. Notes on the captive behaviour of five species of southern African shrews. Säugetierkundliche Mitteilungen 28: 55-62.

Baxter R. M. and Meester J. 1982. The captive behaviour of the red musk shrew, Crocidura $f$. flavescens (I. Geoffroy, 1827) (Soricidae: Crocidurinae). Mammalia 46: 11-27.

Barnard C. J. 1984. Shrews. [In: The encyclopaedia of animals. D. W. MacDonald, ed]. Equinox Ltd., Oxford: $758-763$.

Bee J. W., Murariu D. and Hoffmann R. S. 1980. Histology and histochemistry of specialised integumentary glands in eight species of North American shrews (Mammalia, Insectivora). Travaux du Muséum d'Histoire naturelle "Grigore Antipa" 22: 547-569.

Churchfield S. 1990. The natural history of shrews. Christopher Helm (Publishers) Ltd., Bromley: xiv +178 .

Crowcroft P. 1952. Refection in the common shrew. Nature 170: 627-627.

Crowcroft P. 1957. The life of the shrew. Max Reinhardt, London: 1-166.

Dryden G. L. and Conaway C. H. 1970. Anal tonsils of soricids. Journal of Mammalogy 51: 382-384.

Fons R. 1974. Le répertoire comportemental de la Pachyure éstrusque, Suncus etruscus (Savi, 1822). La Terre et la Vie 28: 131-157.

Geraets A. 1978. Wiederkauen und Enddarmlecken bei Spitzmäusen (Insectivora). Säugetierkundliche Mitteilungen 26: 127-131.

Geraets A. 1980. Untersuchungen über Bau und Leistung des Verdauungstrakts von Weißzahnspitzmäusen (Mammalia: Soricidae, Crocidurinae) unterschiedlicher Körpergröße. Ph D thesis, Rheinische Friedrich-Wilhelms-Universität, Bonn: 1-124.

Gove P. B. (ed) 1976. Webster's third new international dictionary (Unabridged). G. \& C. Merriam Company, Publishers, Springfield: 1-2662. 
Haberl W. 1993. Zur Ökologie einheimischer Spitzmäuse (Soricidae, Insectivora) und ihres Lebensraumes am Beispiel eines Waldviertler Feuchtbiotops und experimentelle Bearbeitung ausgewählter ethologischer Fragestellungen. Ph D thesis, University of Vienna, Vienna: $1-265+211$.

Haberl W., Koyasu K., Hirakawa H. and Baxter R. M. 1997. A note on "rectum-licking" in shrews (Soricidae, Insectivora). Journal of Growth 36: 77-81.

Hirakawa H. 1994. Coprophagy in the Japanese hare (Lepus brachyurus): reingestion of all the hard and soft feces during the daytime stay in the form. Journal of Zoology, London 232: 447-456.

Hutterer R. 1976. Deskriptive und vergleichende Verhaltensstudien an der Zwergspitzmaus, Sorex minutus L., und der Waldspitzmaus, Sorex araneus L. (Soricidae - Insectivora - Mammalia). Ph D thesis, University of Vienna, Vienna: 1-319.

Imaizumi Y.-H. 1964. Another record of refection by the shrew. Journal of the Mammalogical Society of Japan 2: 79-81.

Kubo K. and Isomura G. 1996. Presence and structure of anal and vaginal tonsils in the laboratory shrew (Suncus murinus). Anatomischer Anzeiger 178: 251-258.

Lincoln R. J., Boxshall G. A. and Clark P. F. 1982. A dictionary of ecology, evolution and systematics. Cambridge University Press, Cambridge: 1-298.

Loxton R. G., Raffaelli D. and Begon M. 1975. Coprophagy and the diurnal cycle of the common shrew, Sorex araneus. Journal of Zoology, London 177: 449-453.

Luk'yanova I. V. 1974. [Coprophagy in members of the family Soricidae]. Theriologiya Vol. 2. Nauka, Novosibirsk: 283. [In Russian]

Motokawa M. and Abe H. 1996. On the specific names of the Japanese moles of the genus Mogera (Insectivore, Talpidae). Mammal Study 21: 115-123.

Ortmann R. 1960. Die Analregion der Säugetiere. [In: Handbuch der Zoologie - Eine Naturgeschichte der Stämme des Tierreichs, Vol. 8, part 3. J.-G. Helmcke, H. von Lengerken and D. Starck, eds]. Walter de Gruyter and Co., Berlin: 1-68.

Schaffer J. 1940. Die Hautdrüsenorgane der Säugetiere mit besonderer Berücksichtigung ihres histologischen Aufbaues und Bemerkungen über die Proktodäaldrüsen. Urban \& Schwarzenberg, Berlin und Wien: 1-464.

Sharma D. R. 1962. Coprophagy in shrews. Journal of Mammalogy 43: 262-262.

Skarén U. 1978. Feeding behavior, coprophagy and passage of foodstuffs in a captive least shrew. Acta Theriologica 23: 131-140.

Southern H. N. 1942. Periodicity of refection in the wild rabbit. Nature 149: 553-554.

Spencer-Booth Y. 1956. Shrews (Crocidura cassiteridum) on the Scilly isles. Proceedings of the Zoological Society of London 126: 167-170.

Walker E. P. 1964. Mammals of the World (3rd edition, revision by J.-L. Paradiso, 1975). The John Hopkins Press, Baltimore: 1-1500.

Watson J. S. 1954. Reingestion in the wild rabbit, Oryctolagus cuniculus (L.). Proceedings of the Zoological Society of London 124: 615-624.

Received 22 April 1997, accepted 18 September 1997. 